\title{
A Minimal Model for G Protein-Mediated Synaptic Facilitation and Depression
}

\author{
Richard Bertram, ${ }^{1,2}$ Jessica Swanson, ${ }^{1}$ Mohammad Yousef, ${ }^{2}$ Zhong-Ping Feng, ${ }^{3}$ and Gerald W. Zamponi ${ }^{3}$ \\ ${ }^{1}$ Department of Mathematics and ${ }^{2}$ Kasha Institute of Biophysics, Florida State University, Tallahassee, Florida 32306; and ${ }^{3}$ Departments \\ of Physiology and Biophysics and of Pharmacology and Therapeutics, Cellular and Molecular Neurobiology Research Group, \\ University of Calgary, Calgary T2N 4N1, Canada
}

Submitted 27 February 2003; accepted in final form 23 April 2003

Bertram, Richard, Jessica Swanson, Mohammad Yousef, ZongPing Feng, and Gerald W. Zamponi. A minimal model for G proteinmediated synaptic facilitation and depression. J Neurophysiol 90: 1643-1653, 2003; 10.1152/jn.00190.2003. G protein-coupled receptors are ubiquitous in neurons, as well as other cell types. Activation of receptors by hormones or neurotransmitters splits the $\mathrm{G}$ protein heterotrimer into $\mathrm{G} \alpha$ and $\mathrm{G} \beta \gamma$ subunits. It is now clear that $\mathrm{G} \beta \gamma$ directly inhibits $\mathrm{Ca}^{2+}$ channels, putting them into a reluctant state. The effects of $\mathrm{G} \beta \gamma$ depend on the specific $\beta$ and $\gamma$ subunits present, as well as the $\beta$ subunit isoform of the $\mathrm{N}$-type $\mathrm{Ca}^{2+}$ channel. We describe a minimal mathematical model for the effects of $\mathrm{G}$ protein action on the dynamics of synaptic transmission. The model is calibrated by data obtained by transfecting $\mathrm{G}$ protein and $\mathrm{Ca}^{2+}$ channel subunits into tsA-201 cells. We demonstrate with numerical simulations that $\mathrm{G}$ protein action can provide a mechanism for either short-term synaptic facilitation or depression, depending on the manner in which $G$ protein-coupled receptors are activated. The $\mathrm{G}$ protein action performs high-pass filtering of the presynaptic signal, with a filter cutoff that depends on the combination of $\mathrm{G}$ protein and $\mathrm{Ca}^{2+}$ channel subunits present. At stimulus frequencies above the cutoff, trains of single spikes are transmitted, while only doublets are transmitted at frequencies below the cutoff. Finally, we demonstrate that relief of $\mathrm{G}$ protein inhibition can contribute to pairedpulse facilitation.

\section{IN T R O D U C T I O N}

Activity-dependent short-term presynaptic plasticity is an important mechanism for synaptic filtering, determining the type of information that is passed from the presynaptic to the postsynaptic cell (Abbott et al. 1997; Bertram 2001; Markram et al. 1998; Tsodyks and Markram 1997). Facilitation occurs when the probability of transmitter release during presynaptic impulse $N$ is greater than during impulse $N-1$, and may be due to accumulation of free $\mathrm{Ca}^{2+}$ (Matveev et al. 2002; Tang et al. 2000; Yamada and Zucker 1992), accumulation of $\mathrm{Ca}^{2+}$ bound to acceptors at the transmitter release sites (Bertram et al. 1996; Stanley 1986), or both. Depression is the opposite and is most often attributed to a decline in the number of vesicles in the readily releasable pool (Dobrunz et al. 1997; Rosenmund and Stevens 1996). However, another mechanism for synaptic depression involves the inhibition of presynaptic $\mathrm{Ca}^{2+}$ channels through the action of G proteins (Boehm and Betz 1997; Chen and van den Pol 1997; Dittman and Regehr 1996; Qian et al. 1997; Takahashi et al. 1998; Wu and Saggau 1994).

Address for reprint requests: R. Bertram, Dept. of Mathematics, Florida State Univ., Tallahassee, FL 32306 (E-mail: Bertram@math.fsu.edu).
Glutamate, the primary excitatory neurotransmitter in the CNS, inhibits $\mathrm{Ca}^{2+}$ channels and synaptic transmission via metabotropic glutamate receptors. This has been shown in the hippocampus (Baskys and Malenka 1991; Ohno-Shosaku and Yamamoto 1995; Swartz and Bean 1992; Trombley and Westbrook 1992), cerebellum (Chavis et al. 1994; Glaum et al. 1992), neocortex (Burke and Hablitz 1994), striatum (Calabresi et al. 1992; Lovinger et al. 1993), and the brain stem (Takahashi et al. 1996). In many cases, the inhibition appears to be due to a direct action of membrane-delimited $\mathrm{G}$ proteins on $\mathrm{Ca}^{2+}$ channels, rather than an indirect action involving second messengers (Hille 1994; Sahara and Westbrook 1993; Swartz and Bean 1992; Trombley and Westbrook 1992). This direct pathway is utilized by other neurotransmitters, including GABA, norepinephrine, acetylcholine, serotonin, and dopamine (Brody and Yue 2000; Delmas et al. 1998; Herlitze et al. 1996; Hille 1994; Ikeda 1996; Mirotznik et al. 2000). In this study, we describe a minimal mathematical model for the effect of direct $\mathrm{G}$ protein action on short-term synaptic plasticity, demonstrating that synaptic transmission can be either facilitated or depressed, depending on the pathway through which $\mathrm{G}$ protein-coupled receptors are activated.

Synaptic transmission is mediated primarily by N- and P/Qtype $\mathrm{Ca}^{2+}$ channels colocalized with synaptic vesicles (Catterall 1995; Dunlap et al. 1995; Llinás et al. 1992; Simon and Llinás 1985). Both channel types are subject to modulation by $\mathrm{G} \beta \gamma$ dimers (Herlitze et al. 1996; Ikeda 1996), which are uncoupled from the $\mathrm{G} \alpha$ subunit on binding of a transmitter or hormone molecule to a $\mathrm{G}$ protein-coupled receptor. The channel-G $\beta \gamma$ complex typically has a reduced activation rate and an increased deactivation rate. A complexed channel is said to be in a "reluctant" state, while an uncomplexed channel is in a "willing" state (Bean 1989; Boland and Bean 1993).

There are 5 known $\mathrm{G} \beta$ isoforms and 11 known $\mathrm{G} \gamma$ isoforms (Betty et al. 1998), and transient transfection studies have shown that different isoform combinations produce different inhibitory effects on $\mathrm{Ca}^{2+}$ channels (Arnot et al. 2000; Diversé-Pierluissi et al. 2000; García et al. 1998; Ruiz-Velasco and Ikeda 2000; Zhou et al. 2000). In most cases, G $\beta \gamma$ dissociates from channels when the membrane is depolarized (Boland and Bean 1993; Hille 1994; Zamponi and Snutch 1998).

\footnotetext{
The costs of publication of this article were defrayed in part by the payment of page charges. The article must therefore be hereby marked "advertisement" in accordance with 18 U.S.C. Section 1734 solely to indicate this fact.
} 
We have recently shown through mathematical modeling that the differential effects on channel kinetics can be explained by different $\mathrm{G} \beta \gamma$ dissociation rates (Bertram et al. 2002).

The N-type $\mathrm{Ca}^{2+}$ channel consists of a pore-forming $\alpha_{1}$ subunit and ancillary $\alpha_{2^{-}-} \delta$ and $\beta$ subunits (Witcher et al. 1993). Four different genes for calcium channel $\beta\left(\mathrm{Ca}_{\mathrm{v}} \beta\right)$ subunits have been identified (Castellano et al. 1993). The $\mathrm{Ca}_{\mathrm{v}} \beta$ subunit and $\mathrm{G} \beta \gamma$ share binding sites on the channel's $\alpha_{1}$ subunit (Chen et al. 1995; Pragnell et al. 1994), so it is not surprising that the presence of the $\mathrm{Ca}_{\mathrm{v}} \beta$ subunit can antagonize G protein action (Bourinet et al. 1996; Campbell et al. 1995; Canti et al. 2000). However, the story appears to be more complicated than simple competition for binding sites. In one study, it was shown that $\mathrm{Ca}_{\mathrm{v}} \beta$ promoted $\mathrm{G}$ protein action (Meir et al. 2000), while another study showed enhanced G $\beta \gamma$ dissociation from the channel when the $\mathrm{Ca}_{\mathrm{v}} \beta_{3}$ isoform was present (Roche and Treistman 1998). Most recently, it was demonstrated that the effects of coexpression of $\mathrm{Ca}_{\mathrm{v}} \beta$ and $\mathrm{G} \beta \gamma$ subunits depend on the specific isoforms expressed (Feng et al. 2001). For some $\mathrm{G} \beta \gamma-\mathrm{Ca}_{\mathrm{v}} \beta$ combinations, there was rapid relief of $\mathrm{G}$ protein inhibition during voltage depolarization, or rapid return to a reluctant state following depolarization, while for other combinations, these processes were slow.

In this paper, we construct a minimal mathematical model to predict the effects of presynaptic G protein action on synaptic transmission, assuming that transmitter release is evoked by $\mathrm{Ca}^{2+}$ entry through $\mathrm{N}$-type channels. This implementation captures the most important features of $G$ protein action, namely 1) a willing-to-reluctant rate that depends on the concentration of activated $\mathrm{G}$ proteins and 2) a reluctant-to-willing rate that increases with membrane depolarization. We use this model to demonstrate that $\mathrm{G}$ protein action can mediate either short-term facilitation or depression, depending on the manner in which $G$ protein-coupled receptors are activated. Thus this plasticity mechanism is more versatile than other mechanisms such as accumulation of free/bound $\mathrm{Ca}^{2+}$ or depletion of the readily releasable vesicle pool. We demonstrate that presynaptic $\mathrm{G}$ protein action performs a high-pass filtering function, so that high-frequency signals are transmitted while low-frequency signals are suppressed. This result is consistent with earlier modeling studies in which more detailed models of $\mathrm{G}$ protein action and the secretion process were employed (Bertram 2001; Bertram et al. 2002).

Given the differential effects of the various $\mathrm{G} \beta \gamma-\mathrm{Ca}_{\mathrm{v}} \beta$ combinations on channel kinetics, what effect would these differences have on neuronal signal processing? We calibrated our mathematical model against voltage clamp data obtained by transiently transfecting human embryonic kidney tsA-201 cells with genes for $\mathrm{Ca}^{2+}$ channel subunits $\alpha_{1 \mathrm{~B}}+\alpha_{2}-\delta$, with $\mathrm{G} \gamma_{2}$, and with combinations of $\mathrm{G} \beta$ and channel $\beta$ subunits. With the model thus calibrated, we show how the high-pass filter cutoff (the frequency below which the synaptic signal is suppressed) varies with different $\mathrm{G} \beta-\mathrm{Ca}_{\mathrm{v}} \beta$ combinations. We also demonstrate that while trains of action potentials at frequencies below the filter cutoff are suppressed, trains of spike doublets are transmitted. Thus the $\mathrm{G}$ protein action creates a switch for the type of impulse pattern that is transmitted; at frequencies above the filter cutoff, trains of single action potentials are transmitted, while at frequencies below the cutoff doublets, but not single spikes, are transmitted. We also consider the situation where more than one $\mathrm{G} \beta-\mathrm{Ca}_{\mathrm{v}} \beta$ combination is activated, as may well be the case given the extensive expression of the different $\mathrm{G} \beta \gamma$ isoforms (Betty et al. 1998).

Paired-pulse facilitation is often attributed to residual free or bound $\mathrm{Ca}^{2+}$ brought into the terminal during the first of two impulses (Zucker and Regehr 2002). However, depolarizationinduced relief of $\mathrm{G}$ protein inhibition can also contribute to this. We demonstrate with numerical simulations that the contribution made by relief of $\mathrm{G}$ protein inhibition to paired-pulse facilitation depends on the activated $\mathrm{G} \beta-\mathrm{Ca}_{\mathrm{v}} \beta$ combination. For some combinations, the facilitation will only last a short time $(<20 \mathrm{~ms})$. For other combinations, facilitation will last significantly longer and contribute to longer-lasting forms of facilitation.

\section{METHODS}

\section{Experimental}

Many of the experimental data used for the present modeling work were derived from the same experiments reported by us and described in detail previously (Feng et al. 2001). New data recorded for the present study (e.g., Fig. 4) were pooled with our previously reported data. Hence, we only briefly review the experimental procedures. Wild-type calcium channel cDNA constructs were supplied by Dr. Terry Snutch. The G protein cDNA constructs used were the same as those described by us previously (Arnot et al. 2000; Feng et al. 2001).

Human embryonic kidney tsA-201 cells were grown to $80 \%$ confluence in DMEM medium supplemented with $10 \%$ fetal bovine serum and $1 \%$ penicillin-streptomycin. After splitting, cells were plated on glass cover slips at 5-10\% confluence and transfected with calcium channel $\left(\alpha_{1}+\alpha_{2}-\delta_{1}+\beta\right)$ and G protein $(\mathrm{G} \beta+\mathrm{G} \gamma 2)$ subunits and an EGFP reporter gene as described by us previously (Feng et al. 2001). After an approximately 2-day recovery period, cells were transferred to a recording chamber for whole cell patchclamp analysis. Cells were bathed in a recording solution consisting of (in $\mathrm{mM}$ ) $20 \mathrm{BaCl}_{2}, 1 \mathrm{MgCl}_{2}, 10 \mathrm{HEPES}, 40$ tetraethylammonium chloride (TEA-Cl), 10 glucose, and $65 \mathrm{CsCl}$, (pH 7.2 with TEA-OH), and whole cell recordings were performed with an Axopatch 200B amplifier (Axon Instruments, Foster City, CA) and pCLAMP v 7.0. Typically, we used fire-polished patch pipettes (Sutter borosilicate glass, BF150-86-15) with resistances of 3-4 M $\Omega$. The internal pipette solution contained (in $\mathrm{mM}$ ) 108 cesium methanesulfonate, $4 \mathrm{MgCl}_{2}, 9$ EGTA, and 9 HEPES (pH 7.2 with $\mathrm{CsOH}$ ). Data were filtered at $1 \mathrm{kHz}$ and recorded directly onto the hard drive of the computer. Series resistance and capacitance were compensated by $85 \%$. Currents were evoked by stepping from $-100 \mathrm{mV}$ to a test potential of $+20 \mathrm{mV}$. Tonic voltage-dependent $\mathrm{G}$ protein inhibition was determined from the degree of current facilitation that occurred after application of a 50 -ms depolarizing prepulse to $+150 \mathrm{mV} 5 \mathrm{~ms}$ prior to the test depolarization. The time constants for activation (before and after the prepulse) were estimated from monoexponential fits to the late rising phase of the whole cell currents (see Fig. 2). In some cases, relief from $\mathrm{G}$ protein inhibition was induced by application of a rapid train of spike depolarizations to mimic the effects of a train of action potentials (see Fig. 4). The raw data were analyzed using Clampfit and Sigmaplot (Jandel Scientific) software, and figures were generated using Sigmaplot v 4.0.

\section{Mathematical model}

$\mathrm{G}$ protein-induced inhibition of $\mathrm{Ca}^{2+}$ channels occurs when an agonist molecule binds to a $\mathrm{G}$ protein-coupled receptor, causing the replacement of GDP with GTP on the G protein $\alpha$ subunit (Hamm 1998). The $\alpha$ subunit separates from the $\beta \gamma$ dimer, and both $\mathrm{G} \alpha$ and $\mathrm{G} \beta \gamma$ are capable of modulating $\mathrm{Ca}^{2+}$ channel activity. The $\mathrm{G} \alpha$ modulatory pathway involves activation of second messengers and is 
relatively slow (Beech et al. 1992; Bernheim et al. 1991). The G $\beta \gamma$ pathway is direct and involves the binding of the membrane delimited $\mathrm{G} \beta \gamma$ dimer to the I-II loop of the $\mathrm{Ca}^{2+}$ channel's $\alpha_{1}$ subunit (DeWaard et al. 1997; Zamponi et al. 1997), putting the channel into a reluctant state. In this state, the channel's activation rate is decreased, and its deactivation rate increased (Bean 1989), reducing the probability that the channel will open during a brief depolarization such as an action potential. Thus $\mathrm{Ca}^{2+}$ influx during action potentials is primarily through willing channels. Neurotransmitter release from a synaptic terminal is triggered by $\mathrm{Ca}^{2+}$ binding to proteins at the release sites, most notably synaptotagmin (Fernández-Chacón et al. 2001). Thus the quantity of transmitter released from a terminal is greater for larger $\mathrm{Ca}^{2+}$ currents.

We focus on the direct action of $\mathrm{G} \beta \gamma$ on $\mathrm{Ca}^{2+}$ channels. This produces a voltage-dependent form of inhibition, which is relieved by membrane depolarization (Bean 1989) and is due to the dissociation of $\mathrm{G} \beta \gamma$ from the channel (Zamponi and Snutch 1998). A mechanistic model for this process was first described for $\mathrm{N}$-type $\mathrm{Ca}^{2+}$ channels in bullfrog sympathetic neurons (Boland and Bean 1993; Elmslie et al. 1990; Patil et al. 1996), and is the basis for other models (Bertram and Behan 1999; Bertram et al. 2002; Colecraft et al. 2000; Patil et al. 1996). This consists of a channel model with several willing closed states, a willing open state, and a willing $V$-dependent inactivated state. Parallel to this are reluctant closed, open, and inactivated states. The willing-to-reluctant transition rate depends on the concentration of activated $\mathrm{G}$ proteins, while the reluctant-to-willing rate is greater at reluctant closed state $\mathrm{RC}_{\mathrm{n}+1}$ than at $\mathrm{RC}_{\mathrm{n}}$, endowing this transition with voltage dependence.

The mathematical model we describe for synaptic transmission is minimal in the sense that the $\mathrm{G}$ protein inhibition and $V$-dependent relief of inhibition is incorporated into a combined presynapticpostsynaptic model that consists of only a few differential equations. This contrasts with more detailed models that include equations for the various states of $\mathrm{Ca}^{2+}$ channels and $\mathrm{Ca}^{2+}$-bound states of release sites (Bertram 2001; Bertram et al. 2002). The advantages of this minimal implementation are 1 ) the small number of equations makes it amenable to network simulations, and 2) the minimal implementation highlights the features of $\mathrm{G}$ protein action that are most important for signal processing.

The presynaptic component of the model consists of HodgkinHuxley-like equations for membrane potential (Hodgkin and Huxley 1952) and an equation for the fraction of willing $\mathrm{Ca}^{2+}$ channels

$$
\begin{gathered}
\frac{d V}{d t}=-\left(I_{\mathrm{Na}}+I_{\mathrm{K}}+I_{\text {leak }}-I_{\text {app }}\right) / C_{\mathrm{m}} \\
\frac{d n}{d t}=\alpha_{\mathrm{n}}(1-n)-\beta_{\mathrm{n}} n \\
\frac{d w}{d t}=k^{-}(1-w)-k^{+} w
\end{gathered}
$$

where $V$ is presynaptic membrane potential, $n$ is an activation variable for delayed rectifier $\mathrm{K}^{+}$channels, and $w$ is the fraction of willing $\mathrm{Ca}^{2+}$ channels. The membrane capacitance is $C_{\mathrm{m}}=1 \mu \mathrm{Fcm}^{-2}$. The ionic currents are for $\mathrm{Na}^{+}, I_{\mathrm{Na}}=120 m_{\infty}^{3}(1-n)(V-40)$; for $\mathrm{K}^{+}$, $I_{\mathrm{K}}=36 n^{4}(V+77)$; and for the leakage current, $I_{\text {leak }}=0.3(V+55)$ (all in $\mu \mathrm{Acm}^{-2}$ ). External current, $I_{a p p}=10 \mu \mathrm{Acm}^{-2}$, is applied periodically to evoke presynaptic action potentials. The steady-state activation functions are

$$
\begin{gathered}
m_{\infty}(V)=\alpha_{\mathrm{m}} /\left(\alpha_{\mathrm{m}}+\beta_{\mathrm{m}}\right), \quad n_{\infty}(V)=\alpha_{\mathrm{n}} /\left(\alpha_{\mathrm{n}}+\beta_{\mathrm{n}}\right) \\
\alpha_{\mathrm{m}}=0.02(V+40) /(1-\exp [-(V+40) / 10]), \quad \beta_{\mathrm{m}}=8 \exp [-(V+65) / 18]
\end{gathered}
$$

$\alpha_{\mathrm{n}}=0.02(V+55) /(1-\exp [-(V+55) / 10]), \quad \beta_{\mathrm{n}}=0.25 \exp [-(V+65) / 80]$
The parameter $k^{+}$in Eq. 3 is the willing-to-reluctant transition rate, and its value reflects the concentration of activated $G$ proteins. This is determined by the manner in which $G$ proteins are activated: hormonal control or autoactivation. These scenarios are discussed later. The parameter $k^{-}$is the reluctant-to-willing transition rate, and it reflects the $V$-dependent dissociation of $\mathrm{G} \beta \gamma$ from the channel. Since the dissociation rate is known to be greater at depolarized voltages, $k^{-}$ should be an increasing function of the presynaptic voltage. For simplicity, we assume that $k^{-}$has a sigmoid dependence on $V$, with a half-maximum value of $V=0 \mathrm{mV}$. This value is chosen so that inhibition will be relieved during depolarizations to positive voltages, as is shown in numerous experimental studies

$$
k^{-}(V)=\frac{\kappa^{-}}{1+\exp (-V / 5)}
$$

The parameter $\kappa^{-}$is calibrated using kinetic data for different $\mathrm{Ca}_{\mathrm{v}} \beta$ and $\mathrm{G} \beta$ combinations, as discussed later.

The postsynaptic component of the model consists of equations for postsynaptic voltage $\left(V_{\text {post }}\right)$ and $\mathrm{K}^{+}$channel activation $\left(n_{\text {post }}\right)$, and an equation for the fraction of bound neurotransmitter receptors $(s)$

$$
\begin{gathered}
\frac{d V_{\text {post }}}{d t}=-\left(I_{\mathrm{Na}}+I_{\mathrm{K}}+I_{\text {leak }}-I_{\text {syn }}\right) / \mathrm{C}_{\mathrm{M}} \\
\frac{d n_{\text {post }}}{d t}=\alpha_{\mathrm{n}}\left(1-n_{\text {post }}\right)-\beta_{\mathrm{n}} n_{\text {post }} \\
\frac{d s}{d t}=\left[s_{\infty}(V)-s\right] / \tau_{\mathrm{s}}
\end{gathered}
$$

The ionic currents are similar to those used in the presynaptic component, with postsynaptic voltage used in the driving force and in the evaluation of the $\alpha$ and $\beta$ functions. The synaptic current is $I_{\text {syn }}=$ $0.3 s\left(V_{\text {post }}-V_{\text {syn }}\right)$, where $V_{\text {syn }}=0 \mathrm{mV}$, appropriate for an excitatory synapse. The synapse is fast, with $\tau_{\mathrm{s}}=1 \mathrm{~ms}$. We assume that the postsynaptic compartment is capable of generating action potentials.

For model simplification, we omit equations for neurotransmitter release and instead incorporate the fraction of willing presynaptic $\mathrm{Ca}^{2+}$ channels $(w)$ directly into the expression for the fraction of bound postsynaptic receptors, $s$. That is, we make $s_{\infty}(V)$ a sigmoid function with a half-maximal voltage $\left(V_{1 / 2}\right)$ that depends on $w$

$$
\begin{gathered}
s_{\infty}(V)=\frac{1}{1+\exp \left[-\left(V-V_{1 / 2}\right) / 5\right]} \\
V_{1 / 2}=50(1-w)
\end{gathered}
$$

The dependence of $V_{1 / 2}$ on $w$ is chosen so that $V_{1 / 2}$ decreases significantly as more presynaptic $\mathrm{Ca}^{2+}$ channels enter a willing state. Thus when all $\mathrm{Ca}^{2+}$ channels are in a willing state $w=1$, so $V_{1 / 2}=0 \mathrm{mV}$, and presynaptic action potentials (with voltage peak at $V \approx 40 \mathrm{mV}$ ) elicit a large postsynaptic response. When all $\mathrm{Ca}^{2+}$ channels are in a reluctant state $w=0$, so $V_{1 / 2}=50 \mathrm{mV}$ and a presynaptic action potential activates a much smaller fraction of postsynaptic receptors (Fig. 1). Intermediate responses are elicited for $0<w<1$. Thus the $\mathrm{G}$ protein action on presynaptic $\mathrm{Ca}^{2+}$ channels is incorporated directly into the postsynaptic response, omitting the intermediate steps of $\mathrm{Ca}^{2+}$ binding to transmitter release sites and subsequent transmitter release. This simplified model retains the voltage dependence of the $\mathrm{G}$ protein action on $\mathrm{Ca}^{2+}$ channels (through Eq. 7) and the larger postsynaptic response that accompanies relief of $\mathrm{G}$ protein inhibition (through Eq. 12). We point out, however, that the synaptic plasticity is due to a presynaptic mechanism, $G$ protein action, rather than a postsynaptic mechanism.

\section{Numerical solution method}

The solution to the ordinary differential equations was approximated using the software package XPPAUT (Ermentrout 2002). The 


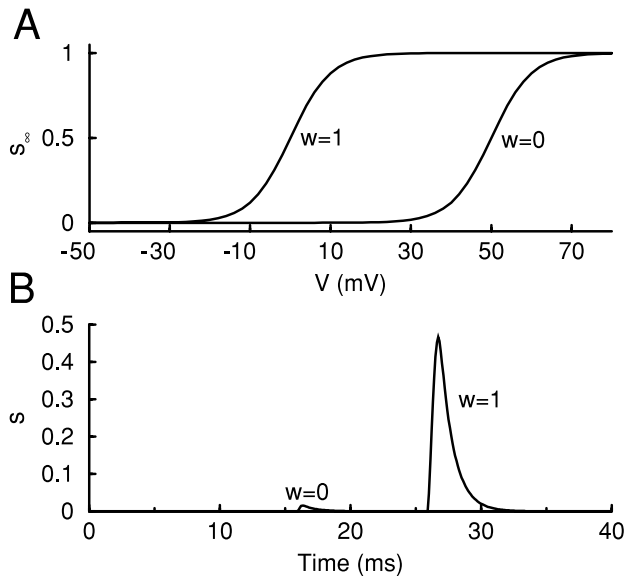

FIG. 1. A: steady-state activation curves $\left(s_{\infty}\right)$ for the synaptic current for 2 different fractions of willing presynaptic $\mathrm{Ca}^{2+}$ channels. $B$ : fraction of activated postsynaptic receptors $(s)$ elicited by a presynaptic action potential, when all presynaptic $\mathrm{Ca}^{2+}$ channels are in a willing state $(w=1)$ or in a reluctant state $(w=0)$.

CVODE solution method was used (also available on the Netlib software distribution web site). This is a variable step size method appropriate for both stiff and nonstiff systems. Error tolerance was $10^{-8}$.

\section{RES U L T S}

\section{Model calibration}

Reluctant $\mathrm{Ca}^{2+}$ channels open more slowly than channels in a willing state, a phenomenon known as kinetic slowing (Bean 1989). Thus in the presence of a $G$ protein-coupled receptor agonist, the time constant for $\mathrm{Ca}^{2+}$ current activation during a voltage-clamp depolarization is larger. The $\mathrm{G}$ protein inhibition can be removed prior to the test pulse with the application of a depolarizing prepulse. Since receptor agonists may be nonspecific, potentially activating several $\mathrm{G}$ protein pathways through various $\mathrm{G}$ protein heterotrimers, transient transfection studies are preferable in the investigation of the differential modulation of $\mathrm{Ca}^{2+}$ channel kinetics by different $\mathrm{G}$ protein components. Figure 2 shows current traces from tsA-201 cells transfected with various subunit combinations. Those traces labeled with $\tau_{-\mathrm{pp}}$ were evoked by depolarization from a holding potential of $-100 \mathrm{mV}$ to a test potential of $+20 \mathrm{mV}$. For those labeled with $\tau_{+\mathrm{pp}}$, a $50-\mathrm{ms}$ prepulse to $+150 \mathrm{mV}$ was applied $5 \mathrm{~ms}$ prior to the test pulse. Kinetic slowing is apparent for each subunit combination, although it is much more extreme for $\mathrm{G} \beta_{1}-\mathrm{Ca}_{\mathrm{v}} \beta_{2 \mathrm{a}}$ (Fig. $2 B$, note longer time scale). For each $\mathrm{G} \beta-\mathrm{Ca}_{\mathrm{v}} \beta$ combination, the time constant of current activation during the test pulse was significantly reduced by prepulse application. In the absence of $\mathrm{G} \beta \gamma$, the activation time constant $\left(\tau_{\text {act }}\right)$ is between 1 and $2 \mathrm{~ms}$ (Table 1). With $\mathrm{G} \beta \gamma$ present, it ranges from approximately $2 \mathrm{~ms}$ to tens of $\mathrm{ms}$, depending on the subunit combination. Time constants for the 20 combinations ( $5 \mathrm{G} \beta$ and $4 \mathrm{Ca}_{\mathrm{v}} \beta$ subunits), without prepulse, are listed in Table 1 .

Without $\mathrm{G} \beta \gamma$, activation time constants reflect the time required for willing channels to move from the first closed state to the open state. With saturating concentrations of $\mathrm{G} \beta \gamma$, as is the case here (Feng et al. 2001), almost all channels are in a reluctant state at the beginning of the test pulse. In this case, $\tau_{\text {act }}$ primarily reflects the time required to move from a reluctant to a willing state. In our model, this is the inverse of the dissociation rate $k^{-}$. Thus

$$
\tau_{\text {act }}=\frac{1}{k^{-}}
$$

so that

$$
\kappa^{-}=\frac{1+\exp \left(-V_{\text {tst }} / 5\right)}{\tau_{\text {act }}}
$$

where $V_{\mathrm{tst}}=20 \mathrm{mV}$ is the test potential. We used Eq. 14 along with the time constant mean values from Table 1 to set $\kappa^{-}$for the various $\mathrm{G} \beta-\mathrm{Ca}_{\mathrm{v}} \beta$ combinations (Table 2). In all simulations and all further discussions, model combinations refer to $\kappa^{-}$values from Table 2 .

\section{Trains of short depolarizations relieve inhibition}

Prior studies have demonstrated that $\mathrm{G}$ protein inhibition of $\mathrm{Ca}^{2+}$ channels can be relieved by trains of short depolarizations (Brody et al. 1997; Williams et al. 1997). We used the mathematical model to predict how different $\mathrm{G} \beta-\mathrm{Ca}_{\mathrm{v}} \beta$ combinations affect the time course of relief during a $50-\mathrm{Hz}$ train of depolarizations from -100 to $150 \mathrm{mV}$, each lasting $2 \mathrm{~ms}$. (Large depolarizations are used here since experimental studies of $\mathrm{G}$ protein inhibition often use similar large depolarizations to demonstrate relief of inhibition. In later model figures, the presynaptic voltage changes only over the range of an action potential.) We assumed a high concentration of $\mathrm{G} \beta \gamma$ (simulating transfection conditions), with $k^{+}=0.004 \mathrm{~ms}^{-1}$ and with all channels initially in a reluctant state $(w=0)$. The simulation in Fig. 3 shows the time course of relief of inhibition for two different subunit combinations, $\mathrm{G}_{3}{ }_{3}-\mathrm{Ca}_{\mathrm{v}} \beta_{1 \mathrm{~b}}$ and $\mathrm{G} \beta_{3^{-}}$ $\mathrm{Ca}_{\mathrm{v}} \beta_{2 \mathrm{a}}$. The figure shows the willing fraction, $w$, scaled by $w$ at the 20th pulse, allowing for time course comparison for the two subunit combinations. The relief rate for $\mathrm{Ca}_{\mathrm{v}} \beta_{1 \mathrm{~b}}$ is greater than for $\mathrm{Ca}_{\mathrm{v}} \beta_{2 \mathrm{a}}$, reflecting the larger $\mathrm{G} \beta \gamma$ dissociation rate.
A
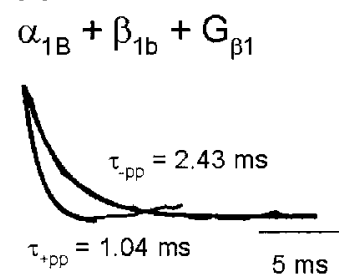

C
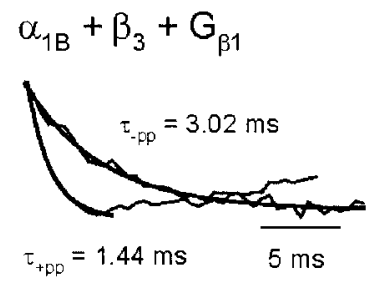

$\mathrm{B}$

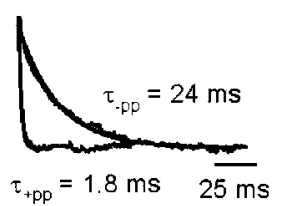

D
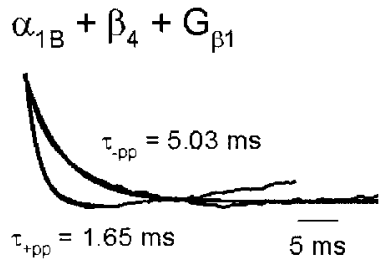

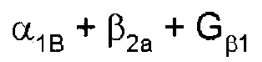

FIG. 2. Currents evoked by depolarization from -100 to $20 \mathrm{mV}$ with different transfected calcium channel $\beta$ subunits, $(A) \beta_{1 \mathrm{~b}},(B) \beta_{2 \mathrm{a}},(C) \beta_{3},(D)$ $\beta_{4}$. In each case, $\mathrm{G} \gamma_{2}$ and calcium channel $\alpha_{2}-\delta_{1}$ was coexpressed. Traces labeled $\tau_{-\mathrm{pp}}$ correspond to currents evoked without prepulse, while for those labeled $\tau_{+\mathrm{pp}}, 50 \mathrm{~ms}$ prepulses to $+150 \mathrm{mV}$ were applied $5 \mathrm{~ms}$ prior to the test pulse. 
TABLE 1. $\mathrm{Ca}^{2+}$ channel activation time constants (ms) for different $G \beta-C a_{v} \beta$ combinations without prepulse

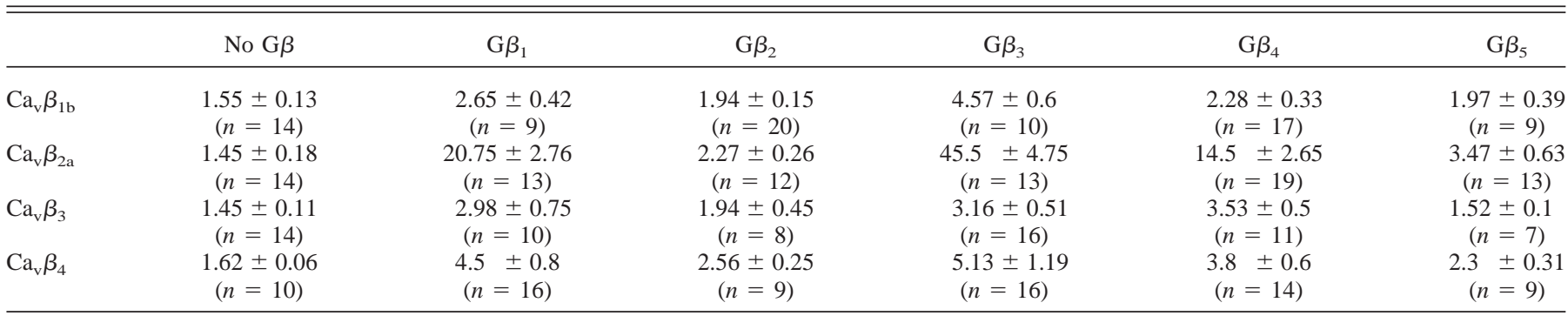

Values are means $\pm \mathrm{SE}$, with number of experiments in parentheses.

Thus fewer pulses are required to relieve inhibition for subunit combinations with larger $\kappa^{-}$, although there is some relief of inhibition even when the dissociation rate is low.

A similar approach was used to investigate relief of $\mathrm{G}$ protein inhibition in transfected tsA-201 cells. Data were generated by applying a $50-\mathrm{Hz}$ train of prepulses (to $150 \mathrm{mV}, 2 \mathrm{~ms}$ duration), with 1-20 depolarizations, followed by a test pulse to $20 \mathrm{mV}$. $\mathrm{Ca}^{2+}$ current was measured $5 \mathrm{~ms}$ after the start of the test pulse. Let $I_{\mathrm{Ca}}(n)$ represent current for the test pulse following $n$ prepulses. To compare the time course of relief from inhibition, $I_{\mathrm{Ca}}(n)$ was scaled by $I_{\mathrm{Ca}}(20)$, normalizing the data. Recordings were made from cells transfected with $\mathrm{G} \beta_{3^{-}}$ $\mathrm{Ca}_{\mathrm{v}} \beta_{1 \mathrm{~b}}$ and with $\mathrm{G} \beta_{3}-\mathrm{Ca}_{\mathrm{v}} \beta_{2 \mathrm{a}}$. As in the simulation, the rate of relief of inhibition was greater with the $\mathrm{G} \beta_{3}-\mathrm{Ca}_{\mathrm{v}} \beta_{1 \mathrm{~b}}$ combination than with the $\mathrm{G} \beta_{2}-\mathrm{Ca}_{\mathrm{v}} \beta_{2 \mathrm{a}}$ combination (Fig. 4). Also, the simulation and the data agree very well for the $\mathrm{G} \beta_{3}-\mathrm{Ca}_{\mathrm{v}} \beta_{2 \mathrm{a}}$ combination, while the relief of inhibition is somewhat more rapid in the simulation than the data for the $\mathrm{G} \beta_{3}-\mathrm{Ca}_{\mathrm{v}} \beta_{1 \mathrm{~b}}$ combination.

\section{Synaptic facilitation through relief of inhibition}

We next consider the potential effects of $\mathrm{G}$ protein inhibition on synaptic transmission, locating $\mathrm{G}$ protein-coupled receptors and $\mathrm{N}$-type $\mathrm{Ca}^{2+}$ channels in the model presynaptic terminal. Receptors may be activated locally by neurotransmitters or diffusely by hormones and peptides. We focus first on the latter case, hormonal control, where the agonist concentration is independent of the electrical activity of pre- and postsynaptic cells.

We assume that the $\mathrm{G}$ protein agonist activates a saturating concentration of $\mathrm{G} \beta \gamma$. Thus all channels are initially in a reluctant state $(w=0)$, and $k^{+}=0.004 \mathrm{~ms}^{-1}$, as in Fig. 3. The results for nonsaturating concentrations are qualitatively similar. The $\mathrm{G} \beta_{3}-\mathrm{Ca}_{\mathrm{v}} \beta_{1 \mathrm{~b}}$ combination is used, so $\kappa^{-}=0.22 \mathrm{~ms}^{-1}$. Trains of presynaptic action potentials are generated, and $w$ and the postsynaptic response are examined. Figure 5, $A$ and $B$, shows the response to a $20-\mathrm{Hz}$ train of impulses. During the train, $w$ increases from 0 to approximately 0.4 (Fig. 5A),

TABLE 2. Dissociation parameter $\kappa^{-}\left(\mathrm{ms}^{-1}\right)$ calibrated with data from Table 1, using Eq. 14

\begin{tabular}{lccccc}
\hline \hline & $\mathrm{G} \beta_{1}$ & $\mathrm{G} \beta_{2}$ & $\mathrm{G} \beta_{3}$ & $\mathrm{G} \beta_{4}$ & $\mathrm{G} \beta_{5}$ \\
\hline $\mathrm{Ca}_{\mathrm{v}} \beta_{1 \mathrm{~b}}$ & 0.38 & 0.52 & 0.22 & 0.45 & 0.52 \\
$\mathrm{Ca}_{\mathrm{v}} \beta_{2 \mathrm{a}}$ & 0.05 & 0.45 & 0.02 & 0.07 & 0.29 \\
$\mathrm{Ca}_{\mathrm{v}} \beta_{3}$ & 0.34 & 0.52 & 0.32 & 0.29 & 0.67 \\
$\mathrm{Ca}_{\mathrm{v}} \beta_{4}$ & 0.23 & 0.40 & 0.20 & 0.27 & 0.44 \\
\hline
\end{tabular}

resulting in a progressively larger postsynaptic response (Fig. $5 B$ ). However, the spike threshold is never reached, and postsynaptic impulses are not generated. Thus the $20-\mathrm{Hz}$ presynaptic signal is filtered out, despite the facilitation of transmitter release that is produced by relief of $\mathrm{G}$ protein inhibition. When the simulation is repeated with a $30-\mathrm{Hz}$ train of impulses, the fraction of willing channels rises to a higher level (Fig. 5C). This results in greater facilitation of the postsynaptic response, and in this case, the postsynaptic cell reaches spike threshold after the ninth stimulus (Fig. 5D). Thus the synaptic facilitation produced by relief of $G$ protein inhibition allows the $30-\mathrm{Hz}$ signal to be transmitted after a few "lost" impulses. Again, we stress that the facilitation has a presynaptic origin, which is reflected in the postsynaptic response.

The simulation in Fig. 5 demonstrates that when $G$ protein activation is under hormonal control, the synaptic response facilitates during trains of presynaptic stimuli, and the degree of facilitation depends on the stimulus frequency. Thus the tonic $\mathrm{G}$ protein inhibition actually provides a mechanism for frequency-dependent synaptic facilitation. This form of facilitation is indistinguishable from facilitation due to the buildup of free or bound $\mathrm{Ca}^{2+}$ in the presynaptic terminal, unless presynaptic $\mathrm{Ca}^{2+}$ measurements are made to determine whether $\mathrm{Ca}^{2+}$ current is increasing during the stimulus train. In fact, the two forms of facilitation would superimpose in a nonlinear way, due to the $\mathrm{Ca}^{2+}$ cooperativity of the transmitter release process (Dodge and Rahamimoff 1967).

Figure 5 also demonstrates that $\mathrm{G}$ protein action performs high-pass filtering on the presynaptic signal. That is, low frequency signals do not produce postsynaptic impulses, so they are filtered out. Impulse trains above a threshold frequency are transmitted after a few lost impulses. The number of lost impulses is smaller at higher frequencies. Significantly, the threshold frequency is different for different $\mathrm{G} \beta-\mathrm{Ca}_{\mathrm{v}} \beta$

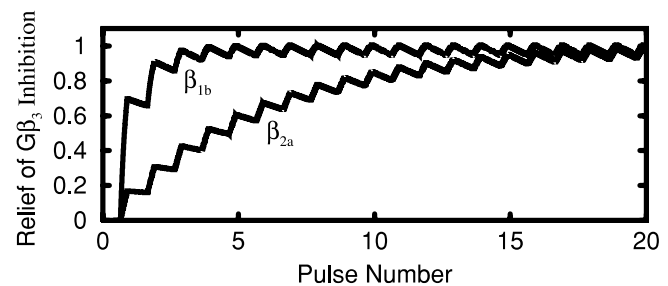

FIG. 3. Simulated time course of relief of inhibition during a 50-Hz train of 2-ms depolarizations from -100 to $150 \mathrm{mV}$, for 2 subunit combinations. In each case, $w$ was scaled by $w$ at pulse 20 so that time courses can be compared. $\mathrm{G}$ protein unbinding rates are $\kappa^{-}=0.22 \mathrm{~ms}^{-1}$ for curve labeled $\beta_{1 \mathrm{~b}}$, and $\kappa^{-}=$ $0.02 \mathrm{~ms}^{-1}$ for curve labeled $\beta_{2 \mathrm{a}}$. 


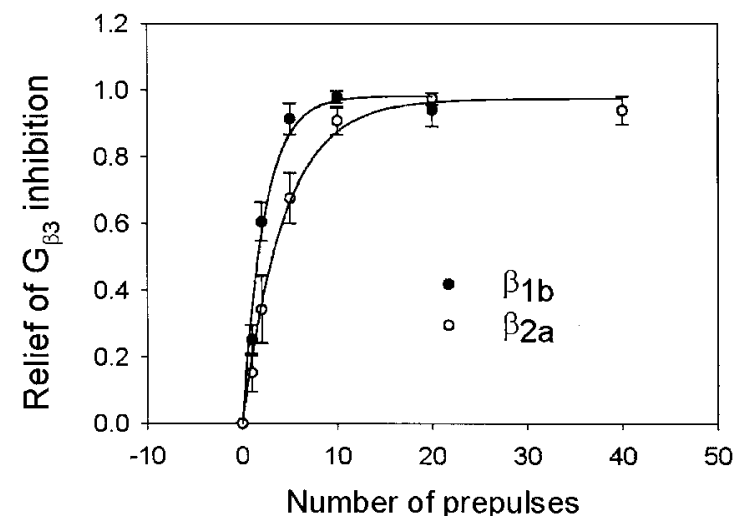

FIG. 4. Time course of relief for 2 subunit combinations in transfected tsA-201 cells. In each case, data were normalized to allow comparison of relief time courses $\left(n=6\right.$ for $\mathrm{G} \beta_{3}-\mathrm{Ca}_{\mathrm{v}} \beta_{1 \mathrm{~b}}, n=5$ for $\left.\mathrm{G} \beta_{3}-\mathrm{Ca}_{\mathrm{v}} \beta_{2 \mathrm{a}}\right)$.

combinations. This will be examined in more detail in the next section.

\section{Synaptic depression through autoinhibition}

G protein-mediated autoinhibition occurs when neurotransmitter molecules released from the presynaptic terminal bind to $\mathrm{G}$ protein-coupled receptors in the terminal. The subsequent activation of $G$ proteins can lead to inhibition of presynaptic $\mathrm{Ca}^{2+}$ current and depression of transmitter release (Chen and van den Pol 1998; Shen and Horn 1996; Shen and Johnson 1997; Wu and Saggau 1997). Here we investigate the effects of different $\mathrm{G} \beta-\mathrm{Ca}_{\mathrm{v}} \beta$ subunit combinations on synaptic depression induced by autoinhibition. Since the focus is on $\mathrm{G}$ protein action, other sources of presynaptic depression, such as the depletion of readily releasable vesicles, are not considered.

In the following simulations we use the basic mathematical model supplemented with a differential equation describing the fraction of bound autoreceptors $(a)$

$$
\frac{d a}{d t}=\left[a_{\infty}(V)-a\right] / \tau_{\mathrm{a}}
$$

where the steady-state fraction is described by an increasing sigmoid function

A

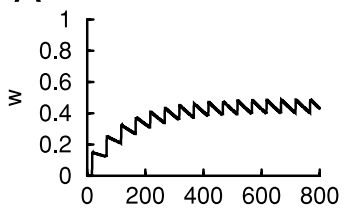

B
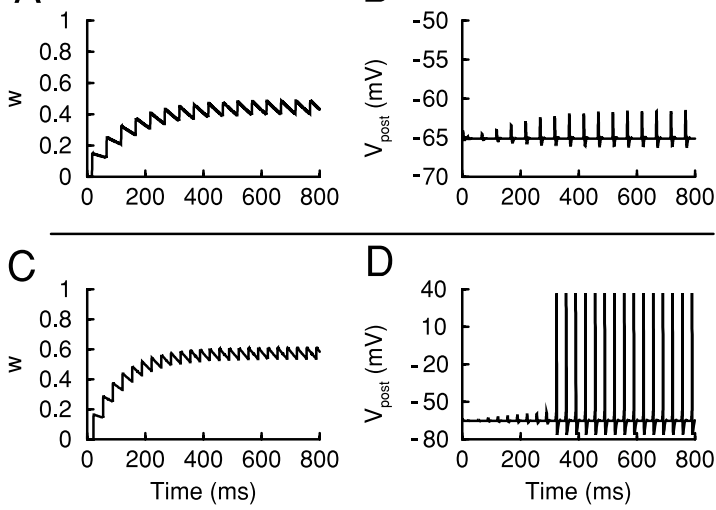

FIG. 5. $A$ and $B$ : fraction of willing presynaptic $\mathrm{Ca}^{2+}$ channels and postsynaptic voltage during a $20-\mathrm{Hz}$ train of presynaptic action potentials. Spike threshold is never reached. $C$ and $D$ : there is more facilitation during a $30-\mathrm{Hz}$ train, allowing the postsynaptic cell to reach the spike threshold after the 9th stimulus. $G$ protein activation is under hormonal control, and $\kappa^{-}$for the $\mathrm{G} \beta_{3}-\mathrm{Ca}_{\mathrm{v}} \beta_{1 \mathrm{~b}}$ combination was used.

$$
a_{\infty}(V)=\frac{1}{1+\exp [-(V+50) / 5]}
$$

and $\tau_{\mathrm{a}}=500 \mathrm{~ms}$. The steady-state function has a half-maximal value at $V=-50 \mathrm{mV}$. This left-shifted curve ensures that there will be a significant increase in $a$ during an action potential. The time constant $\tau_{\mathrm{a}}$ reflects the time required for a transmitter molecule to bind an autoreceptor and for the associated activated $\mathrm{G}$ protein to bind to a $\mathrm{Ca}^{2+}$ channel. We assume that this time constant is large, and show later that $\tau_{a}$ can be varied from 250 to $750 \mathrm{~ms}$ with no effect on the filter properties of $\mathrm{G}$ protein inhibition.

With Eqs. 15 and 16, the fraction of bound autoreceptors slowly accumulates during a train of presynaptic impulses and slowly decays to near 0 following the train. We assume that the rate at which $\mathrm{G} \beta \gamma$ binds to $\mathrm{Ca}^{2+}$ channels is proportional to $a$

$$
k^{+}=\kappa^{+} a
$$

where $\kappa^{+}=0.04 \mathrm{~ms}^{-1}$.

Figure 6 shows the model response to a $10-\mathrm{Hz}$ train of presynaptic impulses. This impulse train causes an accumulation of bound autoreceptors (Fig. 6B), activating G proteins (with the $\mathrm{G}_{3}-\mathrm{Ca}_{\mathrm{y}} \beta_{1 \mathrm{~b}}$ combination), and decreasing the fraction of willing $\mathrm{Ca}^{2+}$ channels (Fig. $6 C$ ). This in turn decreases the fraction of postsynaptic receptors bound during a stimulus, so that by the 11th stimulus, the postsynaptic cell does not reach spike threshold (Fig. 6A). Thus after a transient period during which presynaptic impulses elicit postsynaptic impulses, the $10-\mathrm{Hz}$ signal is filtered out as a result of presynaptic $\mathrm{G}$ protein inhibition. This simulation differs in two important ways from that in Fig. 5. First, the G protein binding rate $k^{+}$is determined by the electrical activity of the presynaptic cell. Second, the initial fraction of willing $\mathrm{Ca}^{2+}$ channels is 1 rather than 0 , since there are initially no bound autoreceptors. As a result of these differences, we see synaptic depression here rather than the synaptic facilitation shown in Fig. 5. Again, the plasticity is due to presynaptic $\mathrm{G}$ protein action.

As in the case of hormonal control, there is a threshold stimulus frequency above which the presynaptic train is trans-
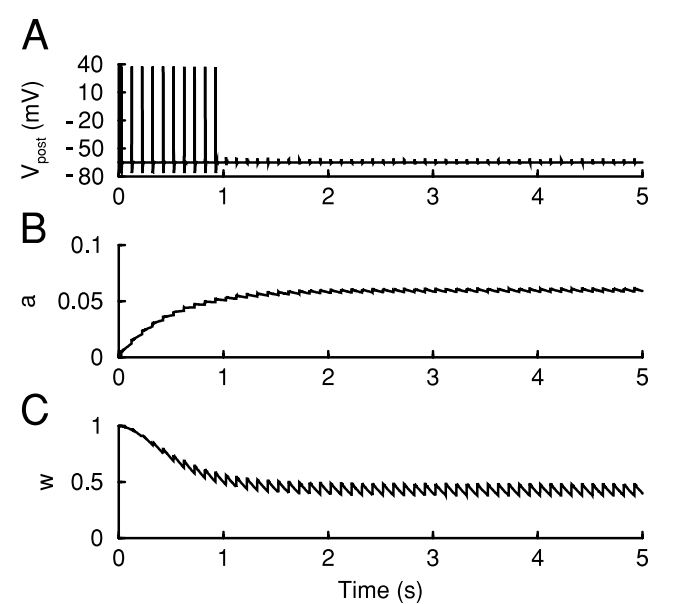

FIG. 6. Simulated response to a $10-\mathrm{Hz}$ presynaptic impulse train, with the $\mathrm{G} \beta_{3}-\mathrm{Ca}_{\mathrm{v}} \beta_{1}$ subunit combination. $A$ : after a transient spiking period, the postsynaptic response is depressed. $B$ : fraction of bound autoreceptors increases due to presynaptic electrical activity. $C$ : responding to the increase in bound $\mathrm{G}$ protein-coupled autoreceptors, the fraction of willing $\mathrm{Ca}^{2+}$ channels declines, depressing the synapse. 
A
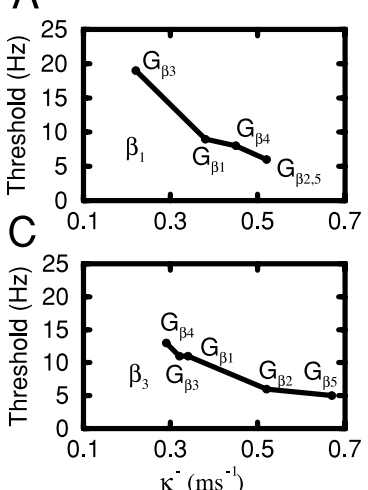

$B$
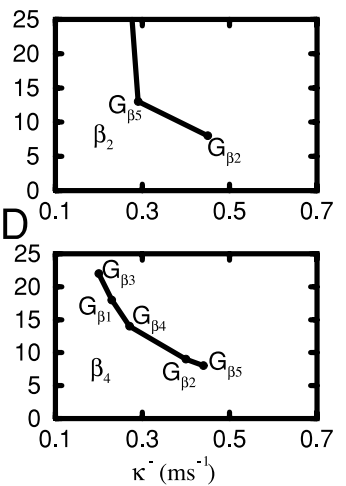

FIG. 7. Transmission thresholds for different $\mathrm{G} \beta-\mathrm{Ca}_{\mathrm{v}} \beta$ subunit combinations, calculated with the model with $(A) \mathrm{Ca}_{\mathrm{v}} \beta_{1 \mathrm{~b}},(B) \mathrm{Ca}_{\mathrm{v}} \beta_{2 \mathrm{a}},(C) \mathrm{Ca}_{\mathrm{v}} \beta_{3},(D)$ $\mathrm{Ca}_{\mathrm{v}} \beta_{4}$. Above threshold, a presynaptic impulse trains is transmitted in its entirety. Below threshold, the postsynaptic response is only transient.

mitted and below which the train is suppressed. This is true despite the fact that a high-frequency train causes the bound autoreceptor fraction to rise to a higher level than a low frequency train. The greater average depolarization of the high-frequency train results in more relief of $G$ protein inhibition, so even though there are more activated $G$ proteins, their effect is diminished. The high-pass filtering makes this form of synaptic depression very different from depression due to depletion of the readily releasable vesicle pool, which acts as a low-pass filter (Bertram 2001; Markram et al. 1998).

The autoinhibition model was used to determine threshold frequencies for the $\mathrm{G}$ protein dissociation values corresponding to all $\mathrm{G} \beta-\mathrm{Ca}_{\mathrm{v}} \beta$ combinations. Each of the four panels of Fig. 7 shows the thresholds corresponding to a single $\mathrm{Ca}^{2+}$ channel $\beta$ subunit, for different $\mathrm{G} \beta$ subunits. For example, the threshold for $\mathrm{G} \beta_{3}-\mathrm{Ca}_{\mathrm{v}} \beta_{1 \mathrm{~b}}$ is nearly $20 \mathrm{~Hz}$, while that for $\mathrm{G} \beta_{2}-\mathrm{Ca}_{\mathrm{v}} \beta_{1 \mathrm{~b}}$ is just $5 \mathrm{~Hz}$ (Fig. 7A). It is interesting to observe the large range of threshold frequencies. This is particularly striking for combinations with the $\mathrm{Ca}_{\mathrm{v}} \beta_{2 \mathrm{a}}$ subunit, where the threshold ranges from 8 to $>100 \mathrm{~Hz}$ (off the scale of the graph) for $\mathrm{G} \beta_{1}, \mathrm{G} \beta_{3}$, and $\mathrm{G} \beta_{4}$ (Fig. $7 B$ ). In fact, for these three subunit combinations, the threshold is so high that all impulse trains with reasonable frequencies are ultimately filtered out and only transient postsynaptic responses can be generated. At the other extreme, combinations such as $\mathrm{G} \beta_{2}-\mathrm{Ca}_{\mathrm{v}} \beta_{1 \mathrm{~b}}, \mathrm{G} \beta_{5}-\mathrm{Ca}_{\mathrm{v}} \beta_{1 \mathrm{~b}}, \mathrm{G} \beta_{2}$ $\mathrm{Ca}_{\mathrm{v}} \beta_{3}$, and $\mathrm{G} \beta_{5}-\mathrm{Ca}_{\mathrm{v}} \beta_{3}$ will transmit all trains at or above $5 \mathrm{~Hz}$.

The simulations thus far have assumed a single $\mathrm{G} \beta-\mathrm{Ca}_{\mathrm{v}} \beta$ combination in the presynaptic terminal. It is possible, however, that more than one $\mathrm{G} \beta \gamma$ isoform is activated by autoreceptors or that more than one type of $\mathrm{Ca}_{\mathrm{v}} \beta$ subunit is expressed in the terminal. One advantage of the minimal model is the ease with which it can be adapted to these situations. This is demonstrated with an example where $\mathrm{G} \beta_{1}$ and $\mathrm{G} \beta_{2}$ are both activated by autoreceptors, and both target channels with $\mathrm{Ca}_{\mathrm{v}} \beta_{2 \mathrm{a}}$ subunits. Then $w_{1}$ and $w_{2}$ are the fraction of willing channels subject to inhibition by $\mathrm{G} \beta_{1}$ and $\mathrm{G} \beta_{2}$, respectively. The dynamics of each variable are described by equations like Eq. 3, with $k^{-}$and $k^{+}$set according to values in Table 2. For $\mathrm{G} \beta_{1}-\mathrm{Ca}_{\mathrm{v}} \beta_{2 \mathrm{a}}$, the dissociation rate $k^{-}$is small, so the filter cutoff is large ( $>100 \mathrm{~Hz}$; Fig. 7). The cutoff for $\mathrm{G} \beta_{2}-\mathrm{Ca}_{\mathrm{v}} \beta_{2 \mathrm{a}}$ is much lower $(<10 \mathrm{~Hz})$.

With these two subpopulations, the fraction of willing channels for the entire population is

$$
w=f_{1} w_{1}+f_{2} w_{2}
$$

where $f_{1}$ and $f_{2}$ are the fractions of channels subject to inhibition from $\mathrm{G} \beta_{1}$ and $\mathrm{G} \beta_{2}$, respectively $\left(f_{1}+f_{2}=1\right)$. This expression for $w$ assumes that $\mathrm{G} \beta_{1}$ and $\mathrm{G} \beta_{2}$ do not compete for the same channels. The effect of $\mathrm{G}$ protein inhibition is then reflected in the postsynaptic cell through Eq. 12 as before.

Figure 8 shows the response of the model synapse to a $50-\mathrm{Hz}$ train of presynaptic impulses. Figure $8, A$ and $B$, shows the response if only $\mathrm{G} \beta_{1}$ is activated by autoreceptors $\left(f_{1}=1, f_{2}=\right.$ $0)$. Here the fraction of willing channel falls to a low level, too low to sustain a postsynaptic response. If both populations of $\mathrm{G} \beta$ are activated, then $w$ is intermediate between $w_{1}$ and $w_{2}$, depending on the values of $f_{1}$ and $f_{2}$ (Fig. 8D). If $f_{1}=0.5$ and $f_{2}=0.5$, so that the channels are split evenly between the two subpopulations, $w$ falls to a value that is still too low to sustain the postsynaptic response. However, with $f_{1}=0.4, f_{2}=0.6$ so that the fraction of channels targeted by $\mathrm{G} \beta_{2}$ is larger than the fraction targeted by $\mathrm{G} \beta_{1}$, the postsynaptic response is sustained (Fig. 8, $C$ and $D$ ). This example illustrates that the filter cutoff can be adjusted up or down by combining one $\mathrm{G} \beta-\mathrm{Ca}_{\mathrm{v}} \beta$ combination with one or more others in the presynaptic terminal.

\section{Paired-pulse facilitation}

A common measure of synaptic enhancement is the pairedpulse facilitation, where the postsynaptic response to the second of two presynaptic stimuli is greater than that during the first stimulus (Zucker and Regehr 2002). One mechanism for this facilitation is the buildup of $\mathrm{Ca}^{2+}$ in the presynaptic terminal (Katz and Miledi 1968). Another mechanism is the partial relief of $\mathrm{G}$ protein-mediated inhibition of $\mathrm{Ca}^{2+}$ channels. This was shown in cultured hippocampal neurons, using short trains of presynaptic stimuli (Brody and Yue 2000). The wide range of $\mathrm{G}$ protein dissociation rates in our model for different $\mathrm{G} \beta-\mathrm{Ca}_{\mathrm{v}} \beta$ combinations allows for the $\mathrm{G}$ protein pathway to contribute to paired-pulse facilitation with a range of decay rates.

The efficacy of the $G$ protein pathway in the enhancement of paired-pulse facilitation depends on the fraction of $\mathrm{Ca}^{2+}$ channels in a willing state at the time of the first impulse. If we
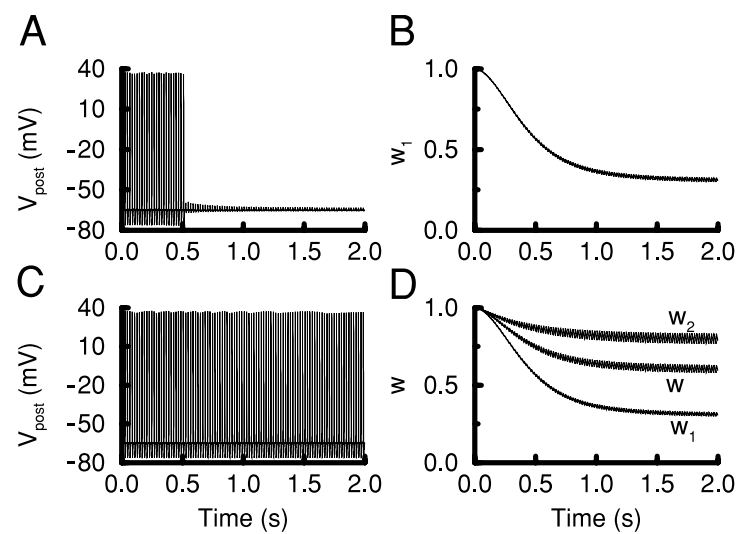

FIG. 8. Response to a 50-Hz impulse train with autoinhibition. $A$ and $B$ : with $\mathrm{G} \beta_{1}-\mathrm{Ca}_{\mathrm{v}} \beta_{2}$, the postsynaptic response is filtered out since the fraction of willing channels falls to a level below what is required to maintain the postsynaptic response. $C$ and $D$ : postsynaptic response is maintained when there are 2 populations of channels, with $w=0.4 w_{1}+0.6 w_{2}$. 

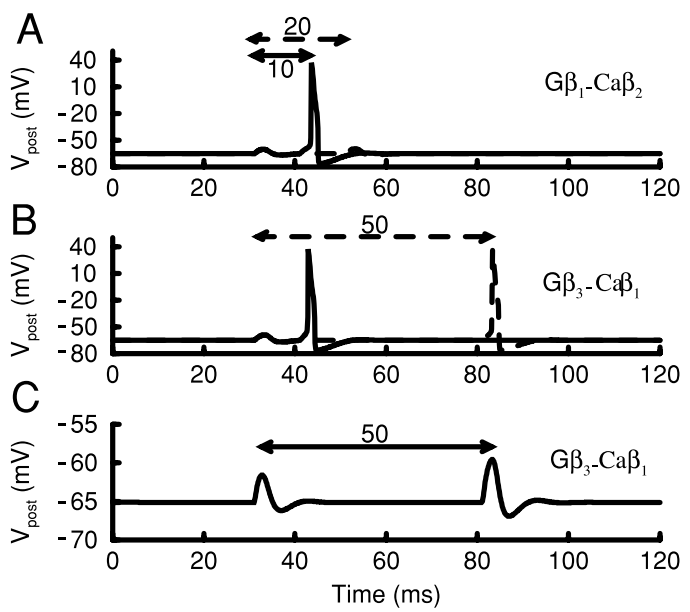

FIG. 9. Partial relief of inhibition produced by a presynaptic stimulus can facilitate the postsynaptic response to the second stimulus, contributing to paired-pulse facilitation. $A$ : with $\mathrm{G} \beta_{1}-\mathrm{Ca}_{\mathrm{v}} \beta_{2}$, the facilitation is small, and produces a 2nd postsynaptic impulse only when the interspike interval is $<20$ ms. $B$ : with $\mathrm{G}_{3}-\mathrm{Ca}_{\mathrm{v}} \beta_{1 \mathrm{~b}}$, the facilitation is greater and lasts longer, producing a 2 nd postsynaptic impulse even with interspike interval of $50 \mathrm{~ms}$. $C$ : when the initial fraction of willing channels is lower $(w=0.4$ rather than $w=0.5)$, facilitation is insufficient to produce a postsynaptic response.

assume auto-activation by released transmitter, the fraction of willing channels depends on the prior activity of the synapse. If the synapse has been silent for many seconds, all channels will be in a willing state at the time of the first impulse, and relief of inhibition is not possible. In this case, the $G$ protein pathway will not contribute to paired-pulse facilitation and instead can contribute to paired-pulse depression. If, on the other hand, there has been recent synaptic activity, or if $\mathrm{G}$ protein receptors have been activated hormonally, some channels will be in a reluctant state at the time of the first stimulus, and the relief of $\mathrm{G}$ protein inhibition can contribute to pairedpulse facilitation.

Figure 9 shows the postsynaptic response to a pair of presynaptic impulses. The model synapse is under autoinhibitory control, with the $\mathrm{G}_{1}-\mathrm{Ca}_{\mathrm{v}} \beta_{2 \mathrm{a}}$ (Fig. 9A) or $\mathrm{G} \beta_{3}-\mathrm{Ca}_{\mathrm{v}} \beta_{1}$ (Fig. 9, $B$ and $C$ ) subunit combination. In Fig. 9, $A$ and $B$, one-half of the $\mathrm{Ca}^{2+}$ channels are initially in a willing state. In Fig. $9 C$, a smaller fraction, $40 \%$, are willing. In each case, although the first stimulus does not evoke a postsynaptic impulse, when presynaptic stimuli are separated by $10 \mathrm{~ms}(100-\mathrm{Hz}$ stimulation frequency), the relief from inhibition induced by the first impulse is sufficient to push the postsynaptic cell above the spike threshold (solid curve, not shown in Fig. 9C). However, with the $\mathrm{G} \beta_{1}-\mathrm{Ca}_{\mathrm{v}} \beta_{2 \mathrm{a}}$ combination, the spike threshold is not reached when the interspike interval is $20 \mathrm{~ms}$ (Fig. 9A, dashed). This is because the partial relief of inhibition induced by the first stimulus was small, and this has largely decayed away by the next stimulus. In contrast, with the $\mathrm{G}_{3}-\mathrm{Ca}_{\mathrm{v}} \beta_{1}$ combination, the first stimulus produces a greater relief of inhibition, so the facilitation is longer lasting. In fact, even with a $50-\mathrm{ms}$ interspike interval, the second stimulus evokes a postsynaptic impulse (Fig. 9B, dashed). However, as explained above, these results depend on the initial fraction of willing channels. When only $40 \%$ are initially willing the facilitation provided by the first stimulus is not large enough to evoke a postsynaptic response with a 50-ms interspike interval, although the second EPSP is larger than the first (Fig. 9C).
In summary, the magnitude of the paired-pulse facilitation produced through the $\mathrm{G}$ protein pathway depends on the $\mathrm{G}$ protein dissociation rate. For a $\mathrm{G} \beta-\mathrm{Ca}_{\mathrm{v}} \beta$ combination with a low dissociation rate, the facilitation is small and short lived. For combinations with a larger dissociation rate, the pairedpulse facilitation is larger and longer lasting. The magnitude of facilitation also depends on the fraction of willing channels at the time of the first stimulus. If this fraction is too high, there will be little chance for relief of inhibition, and thus little paired-pulse facilitation. If the fraction is too low, there will be too few willing channels, even with facilitation, to evoke a postsynaptic impulse.

\section{Doublet detection at subthreshold frequencies}

Neurons often fire with patterns other than ordered periodic trains. One pattern often observed is bursting, where impulses are grouped into clusters followed by periods of quiescence. The simplest burst pattern is the doublet, or two-spike burst. This pattern has been observed, for example, in cerebellar Purkinje cells in vitro (Hounsgaard and Midtgaard 1988; Llinás and Sugimori 1980; Mandelblat et al. 2001) and in vivo (Jaeger and Bower 1994). Doublet patterns have two important frequencies: the interburst frequency and the interspike frequency. We next examine the model postsynaptic response to doublets with various interburst and interspike frequencies, using the $\mathrm{G} \beta_{3}-\mathrm{Ca}_{\mathrm{v}} \beta_{1 \mathrm{~b}}$ subunit combination, which has a threshold frequency of $19 \mathrm{~Hz}$ for trains of single spikes (Fig. 7).

In the simulations, the postsynaptic cell initially responds to the doublet stimuli with doublet responses, since there are initially no bound presynaptic autoreceptors. However, the fraction of bound autoreceptors grows in time, so after this transient response the doublet signal may or may not be transmitted, depending on the interburst and interspike frequencies. Figure 10 shows postsynaptic responses after transient responses have ended. A presynaptic doublet train with interburst frequency of $19 \mathrm{~Hz}$ and interspike frequency of $100 \mathrm{~Hz}$ is transmitted in its entirety (Fig. 10A). This is not surprising, since $19 \mathrm{~Hz}$ is not below the transmission threshold for trains of single spikes. When the interburst frequency is reduced to 5 $\mathrm{Hz}$, well below the threshold for single spikes, the second spike in the burst is transmitted as long as the interspike frequency is sufficiently high. With a $100-\mathrm{Hz}$ interspike frequency, the second spike is transmitted (Fig. 10B), while with a $50-\mathrm{Hz}$
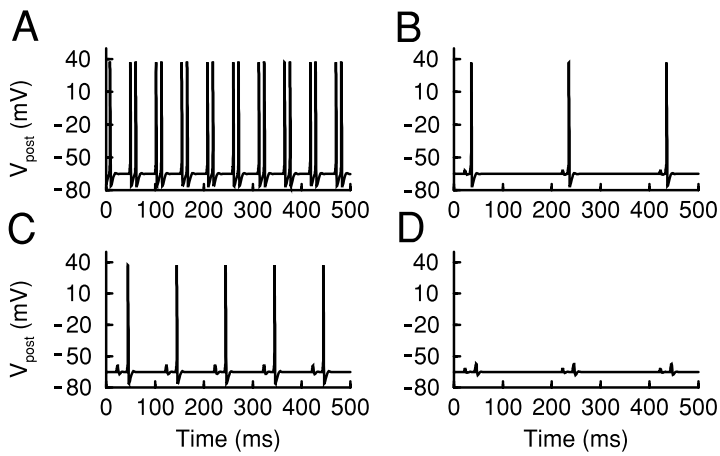

FIG. 10. Model response to trains of doublets, using the $\mathrm{G} \beta_{3}-\mathrm{Ca}_{\mathrm{v}} \beta_{1 \mathrm{~b}}$ subunit combination. Each panel shows the postsynaptic voltage response after transients have ended. Interburst and interspike frequencies are, respectively, (A) 19 and $100 \mathrm{~Hz},(B) 5$ and $100 \mathrm{~Hz},(C) 10$ and $50 \mathrm{~Hz},(D) 5$ and $50 \mathrm{~Hz}$. 
interspike frequency it is not (Fig. 10D). This is because the partial relief from inhibition induced by the first spike is gradually lost. When the interburst frequency is higher (i.e., 10 $\mathrm{Hz}$ ), the $50-\mathrm{Hz}$ interspike frequency is sufficient for transmission of the second spike (Fig. 10C). These simulations show that with $G$ protein autoinhibition, the synapse is a spike detector at superthreshold frequencies and is a doublet detector at subthreshold frequencies. The specific interburst and interspike frequencies are important factors in determining whether the doublet is detected, and these critical frequencies will differ for different $\mathrm{G} \beta-\mathrm{Ca}_{\mathrm{v}} \beta$ subunit combinations.

\section{I S C U S S I O N}

Using numerical simulations, we have illustrated some of the effects that presynaptic $G$ protein action can have on synaptic transmission. These effects can facilitate or depress synaptic activity, depending on the manner of $\mathrm{G}$ protein activation. When under hormonal control, $\mathrm{G}$ protein action provides the synapse with a mechanism for frequency-dependent facilitation. When receptors are activated by transmitters secreted from the synaptic terminal, $G$ protein action acts as a depression mechanism. We have also demonstrated how the different combinations of $\mathrm{G}$ protein $\beta$ subunit and $\mathrm{Ca}^{2+}$ channel $\beta$ subunit can affect the properties of synaptic filtering performed by the action of $\mathrm{G}$ proteins. Simulations with our minimal mathematical model, calibrated with data from transfected tsA-201 cells, show that $G$ protein action acts as a high-pass filter on presynaptic impulse trains. The filter cutoff varies greatly depending on the subunit combination, from 5 to $>100 \mathrm{~Hz}$.

There are currently 5 known $\mathrm{G} \beta$ isoforms, $11 \mathrm{G} \gamma$ isoforms, and $4 \mathrm{Ca}_{\mathrm{v}} \beta$ isoforms, so the number of $\mathrm{G} \beta \gamma-\mathrm{Ca}_{\mathrm{v}} \beta$ combinations is quite large. It is likely that more than one combination will be expressed in a synapse, so in physiological situations several combinations may be active at the same time. We have shown how our minimal model can be adapted to account for the coexistence of several $\mathrm{G} \beta \gamma-\mathrm{Ca}_{\mathrm{v}} \beta$ combinations. With two combinations, the filter threshold is intermediate between the thresholds of each combination. Thus while some $\mathrm{G} \beta \gamma-\mathrm{Ca}_{\mathrm{v}} \beta$ combinations alone may filter out presynaptic impulse trains at virtually all frequencies, their physiological role may be to modulate upward the cutoff frequency of another coexpressed $\mathrm{G} \beta \gamma-\mathrm{Ca}_{\mathrm{v}} \beta$ combination. Indeed, activation of two $\mathrm{G} \beta \gamma-\mathrm{Ca}_{\mathrm{v}} \beta$ combinations in the same synapse would seem to endow the synapse with a great deal of flexibility. By adjusting the size of the two subpopulations, perhaps by adjusting relative gene expression, the cell can dynamically change the filter cutoff to any value between the thresholds of the two subpopulations alone.

One measure of facilitation in synapses is paired-pulse facilitation. The facilitation of transmitter release during a second voltage pulse brought about by a preceding pulse is likely due to several factors, including residual free and bound $\mathrm{Ca}^{2+}$ (Zucker and Regehr 2002). Transient relief of G protein inhibition can also contribute to paired-pulse facilitation. With model simulations, we have demonstrated that the efficacy of this pathway depends on the $\mathrm{G} \beta \gamma-\mathrm{Ca}_{\mathrm{v}} \beta$ combination (Fig. 9). When the $\mathrm{G} \beta \gamma$ dissociation rate is low, the two pulses must be spaced closely together in time for relief from $G$ protein inhibition to contribute greatly to paired-pulse facilitation.
Hence, this pathway could contribute only to the shortest form. When the $\mathrm{G} \beta \gamma$ dissociation rate is high, the relief that occurs during the first impulse is greater and its decay rate lower, so transmitter release is facilitated for longer periods of time. This pathway could contribute to longer forms of facilitation.

Impulses are often clustered into bursts, with two or more impulses per burst. Our examination of the effects of autoinhibition on doublets, or two-spike bursts, shows that the model synapse can detect doublet trains at interburst frequencies well below the filter cutoff for trains of single spikes. Thus below the filter cutoff the nature of the signal transmitted from presynaptic to postsynaptic cell changes. It has previously been demonstrated that vesicle depletion and synaptic facilitation can each determine the type of information transmitted by a synapse (Markram et al. 1998; Tsodyks and Markram 1997). G protein action joins these other forms of short-term plasticity in providing a filter for the type of information transmitted.

In Fig. 7, we showed the effect that the $\mathrm{G} \beta \gamma$ dissociation rate $\kappa^{-}$has on the filter threshold during a train of single impulses, where $\mathrm{G}$ protein activation is through autoinhibition. There are other parameters in the model that may also influence the threshold. In Fig. 11, we compare the effects of three parameters: the $G \beta \gamma$ dissociation rate $\kappa^{-}$, the binding rate $\kappa^{+}$, and the autoreceptor time constant $\tau_{\mathrm{a}}$. The sensitivity of the filter threshold to each of these parameters is quantified by examining the effects of fractional parameter changes. That is, parameter values were set at $\kappa^{-}=0.22 \mathrm{~ms}^{-1}, \kappa^{+}=0.04 \mathrm{~ms}^{-1}$, and $\tau_{\mathrm{a}}=500 \mathrm{~ms}$, the values for the $\mathrm{G}_{3}-\mathrm{Ca}_{\mathrm{v}} \beta_{1 \mathrm{~b}}$ combination. Then each parameter, Par, was varied separately from one-half to three-halves its default value. This yields three curves, one for each parameter. Varying $\tau_{\mathrm{a}}$ had no effect on the filter threshold, indicating that the threshold is insensitive to changes in $\tau_{\mathrm{a}}$ from 250 to $750 \mathrm{~ms}$. In contrast, larger values of $\kappa^{+}$increased the filter cutoff, consistent with the intuition that when there is more $\mathrm{G} \beta \gamma$ binding it takes a stimulus with higher frequency to relieve the inhibition. The threshold is most sensitive to the $\mathrm{G} \beta \gamma$ dissociation parameter, particularly for smaller values of $\kappa^{-}$. This suggests that variation of the $\mathrm{G}$ protein dissociation rate is the most effective way to modulate the filter threshold.

The mathematical model used in this study was developed so as to capture fundamental properties of presynaptic $G$ protein action while using the minimum number of equations: 1) a willing-to-reluctant transition rate that increases with the fraction of activated $G$ proteins, and 2) a reluctant-to-willing transition rate that increases with depolarization. The advantage of this minimal implementation is that it highlights the most important properties of $\mathrm{G}$ protein action on synaptic transmission and it is more amenable to network simulations than more detailed models. We have tested that one detailed

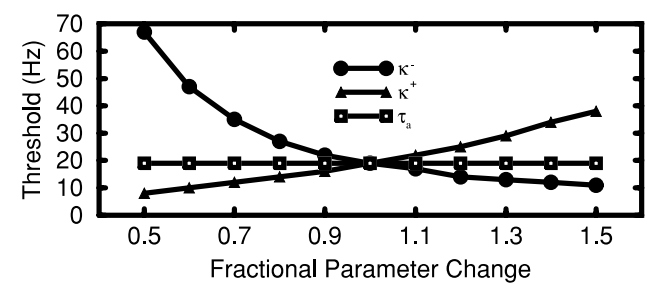

FIG. 11. Sensitivity of the filter threshold to changes in the parameters $\kappa^{-}$, $\kappa^{+}$, and $\tau_{\mathrm{a}}$. Each parameter Par is varied from 0.5Par to 1.5Par, from default values of $\kappa^{-}=0.22 \mathrm{~ms}^{-1}, \kappa^{+}=0.04 \mathrm{~ms}^{-1}$, and $\tau_{\mathrm{a}}=500 \mathrm{~ms}$. The threshold is most sensitive to the $\mathrm{G} \beta \gamma$ dissociation parameter $\kappa^{-}$. 
model (Bertram et al. 2002) can reproduce the behavior of this simpler minimal model (unpublished observations). The target of activated $\mathrm{G}$ proteins assumed in the model, direct inhibition of $\mathrm{N}$-type $\mathrm{Ca}^{2+}$ channels, is one prevalent pathway for $\mathrm{G}$ protein action. An alternate pathway, observed in a lamprey reticulospinal/motoneuron synapse (Blackmer et al. 2001), involves direct action of $\mathrm{G} \beta \gamma$ on the vesicle fusion machinery, downstream of $\mathrm{Ca}^{2+}$ entry. The effects of this pathway on short-term plasticity have not been investigated. In general, while some progress has been made in understanding the potential effects of presynaptic $\mathrm{G}$ protein action on networks of neurons, much more needs to be done to elucidate the role of these ubiquitous messengers in synaptic signal processing. Computational investigations can play a major role in this effort.

We thank Dr. Terry Snutch for providing wild-type rat calcium channel subunits.

\section{I S C L OS URES}

This work was supported by an operating grant to G. W. Zamponi from the Canadian Institutes of Health Research (CIHR). G. W. Zamponi is a CIHR Investigator and holds a Senior Scholar Award from the Alberta Heritage Foundation for Medical Research. Z.-P. Feng held a CIHR postdoctoral fellowship and is currently at the University of Toronto. R. Bertram was supported by National Science Foundation Grant DMS-9981822. M. Yousef is on leave of absence from the Biophysics Department, Faculty of Science, Cairo University, Egypt.

\section{REFERENCES}

Abbott LF, Varela JA, Sen K, and Nelsen SB. Synaptic depression and cortical gain control. Science 275: 220-224, 1997.

Arnot MI, Stotz SC, Jarvis SE, and Zamponi GW. Differential modulation of N-type $\alpha_{1 \mathrm{~B}}$ and P/Q-type $\alpha_{1 \mathrm{~A}}$ calcium channels by different G protein $\beta$ subunit isoforms. J Physiol 527: 203-212, 2000.

Baskys A and Malenka RC. Agonists at metabotropic glutamate receptors presynaptically inhibit EPSCs in neonatal rat hippocampus. $J$ Physiol 444: 687-701, 1991.

Bean BP. Neurotransmitter inhibition of neuronal calcium currents by changes in channel voltage dependence. Nature 340: 153-156, 1989.

Beech DJ, Bernheim L, and Hille B. Pertussis toxin and voltage dependence distinguish multiple pathways modulating calcium channels of rat sympathetic neurons. Neuron 8: 97-106, 1992.

Bernheim L, Beech DJ, and Hille B. A diffusible second messenger mediates one of the pathways coupling receptors to $\mathrm{Ca}^{2+}$ channels in rat sympathetic neurons. Neuron 6: 859-867, 1991.

Bertram R. Differential filtering of two presynaptic depression mechanisms. Neural Comput 13: 69-85, 2001.

Bertram R, Arnot MI, and Zamponi GW. Role for G protein G $\beta \gamma$ isoform specificity in synaptic signal processing: a computational study. J Neurophysiol 87: 2612-2623, 2002.

Bertram R and Behan M. Implications of G-protein-mediated $\mathrm{Ca}^{2+}$ channel inhibition for neurotransmitter release and facilitation. J Comput Neurosci 7 : 197-211, 1999.

Bertram R, Sherman A, and Stanley EF. Single-domain/bound calcium hypothesis of transmitter release and facilitation. J Neurophysiol 75: 1919 1931, 1996.

Betty M, Harnish SW, Rhodes KJ, and Cockett MI. Distribution of heterotrimeric G-protein $\beta$ and $\gamma$ subunits in the rat brain. Neuroscience 85: 475-486, 1998.

Blackmer T, Larsen EC, Takahashi M, Martin TFJ, Alford S, and Hamm HE. G protein $\beta \gamma$ subunit-mediated presynaptic inhibition: regulation of exocytotic fusion downstream of $\mathrm{Ca}^{2+}$ entry. Science 292: 293-297, 2001.

Boehm S and Betz H. Somatostatin inhibits excitatory transmission at rat hippocampal synapses via presynaptic receptors. J Neurosci 17: 40664075, 1997.

Boland LM and Bean BP. Modulation of N-type calcium channels in bullfrog sympathetic neurons by luteinizing hormone-releasing hormone: kinetics and voltage dependence. J Neurosci 13: 516-533, 1993.
Bourinet E, Soong TW, Stea A, and Snutch TP. Determinants of the G-protein dependent opioid modulation of neuronal calcium channels. Proc Natl Acad Sci USA 93: 1486-1491, 1996.

Brody DL, Patil PG, Mulle JG, Snutch TP, and Yue DT. Bursts of action potential waveforms relieve G-protein inhibition of recombinant P/Q-type $\mathrm{Ca}^{2+}$ channels in HEK 293 cells. J Physiol 769: 637-644, 1997.

Brody DL and Yue DT. Relief of G-protein inhibition of calcium channels and short-term synaptic facilitation in cultured hippocampal neurons. $\mathrm{J} \mathrm{Neu}$ rosci 20: 889-898, 2000.

Burke JP and Hablitz JJ. Presynaptic depression of synaptic transmission mediated by activation of metabotropic glutamate receptors in rat neocortex. J Neurosci 14: 5120-5130, 1994.

Calabresi P, Mecuri NB, and Bernardi G. Activation of quisqualic acid metabotropic receptors reduces glutamate and GABA-mediated synaptic potentials in the rat striatum. Neurosci Lett 139: 41-44, 1992.

Campbell V, Berrow NS, Fitzgerald EM, Brickley K, and Dolphin AC. Inhibition of the interaction of $\mathrm{G}$ protein $\mathrm{G}_{\mathrm{o}}$ with calcium channels by the calcium channel $\beta$-subunit in rat neurones. J Physiol 485: 365-372, 1995.

Canti C, Bodnanov Y, and Dolphin AC. Calcium channel $\beta$ subunits bind reversibly to $\alpha_{1 \mathrm{~B}}$ calcium channels: concentration-dependent effect on activation and G protein modulation. Biophys J 78: 200A, 2000.

Castellano A, Wei X, Birnbaumer L, and Perez-Reyes E. Cloning and expression of a neuronal calcium channel $\beta$ subunit. J Biol Chem 268: 12359-12366, 1993.

Catterall WA. Structure and function of voltage-gated ion channels. Ann Rev Biochem 64: 493-531, 1995.

Chavis P, Shinozaki H, Bockaert J, and Fagni L. The metabotropic glutamate receptor types $2 / 3$ inhibit L-type calcium channels via a pertussis toxin-sensitive G-protein in cultured cerebellar granule cells. J Neurosci 14: 7067-7076, 1994.

Chen G and van den Pol AN. Adenosine modulation of calcium currents and presynaptic inhibition of GABA release in suprachiasmatic and arcuate nucleus neurons. J Neurophysiol 77: 3035-3047, 1997.

Chen $\mathbf{G}$ and van den Pol AN. Presynaptic $\mathrm{GABA}_{\mathrm{B}}$ autoreceptor modulation of P/Q-type calcium channels and GABA release in rat suprachiasmatic nucleus neurons. J Neurosci 18: 1913-1922, 1998.

Chen J, DeVivo M, Dingus J, Harry A, Li J, Sui J, Carty DJ, Blamk JL, Exton JH, and Stoffel RH. A region of adenylyl cyclase 2 critical for regulation by G protein subunits. Science 268: 1166-1169, 1995.

Colecraft HM, Patil PG, and Yue DT. Differential occurrence of reluctant openings in G-protein-inhibited N- and P/Q-type calcium channels. J Gen Physiol 115: 175-192, 2000.

Delmas P, Abogadie FC, Dayrell M, Haley JE, Milligan G, Caulfield MP, Brown DA, and Buckley NJ. G-proteins and G-protein subunits mediating cholinergic inhibition of $\mathrm{N}$-type calcium currents in sympathetic neurons. Eur J Neurosci 10: 1654-1666, 1998.

DeWaard M, Liu H, Walker D, Scott VES, Gurnett CA, and Campbell KP. Direct binding of $\mathrm{G}$ protein $\beta \gamma$ complex to voltage-dependent calcium channels. Nature 385: 446-450, 1997.

Dittman JS and Regehr WG. Contributions of calcium-dependent and calcium-independent mechanisms to presynaptic inhibition at a cerebellar synapse. J Neurosci 16: 1623-1633, 1996.

Diversé-Pierluissi M, McIntyre WE, Myung C-S, Lindorfer MA, Garrison JC, Goy MF, and Dunlap K. Selective coupling of G protein $\beta \gamma$ complexes to inhibition of $\mathrm{Ca}^{2+}$ channels. J Biol Chem 275: 28380-28385, 2000.

Dobrunz LE, Huang EP, and Stevens CF. Very short-term plasticity in hippocampal synapses. Proc Natl Acad Sci USA 94: 14843-14847, 1997.

Dodge FA and Rahamimoff R. Co-operative action of calcium ions in transmitter release at the neuromuscular junction. J Physiol 193: 419-432, 1967.

Dunlap K, Luebke JL, and Turner TJ. Exocytotic $\mathrm{Ca}^{++}$channels in the mammalian central nervous system. Trends Neurosci 18: 89-98, 1995.

Elmslie KS, Zhou W, and Jones SW. LHRH and GTP- $\gamma$-S modify activation of N-type calcium currents in bullfrog sympathetic neurons. Neuron 5: 75-80, 1990.

Ermentrout GB. Simulating, Analyzing, and Animating Dynamical Systems: A Guide to XPPAUT for Researchers and Students. Philadelphia, PA: SIAM, 2002.

Feng Z-P, Arnot MI, Doering CJ, and Zamponi GW. Calcium channel $\beta$ subunits differentially regulate the inhibition of N-type channels by individual G $\beta$ isoforms. J Biol Chem 48: 45051-45058, 2001. 
Fernández-Chacón R, Königstorfer A, Gerber SH, Garcia J, Matos MF, Stevens CF, Brose N, Rizo J, Rosenmund C, and Südhof TC. Synaptotagmin I functions as a calcium regulator of release probability. Nature 410: 41-49, 2001.

García DE, Li B, García-Ferreiro RE, Hernández-Ochoa EO, Yan K, Gautam N, Catterall WA, Mackie K, and Bille B. G-protein $\beta$-subunit specificity in the fast membrane-delimited inhibition of $\mathrm{Ca}^{2+}$ channels. J Neurosci 18: 9163-9170, 1998.

Glaum SR, Slater NT, Rossi DJ, and Miller RJ. Role of metabotropic glutamate (ACPD) receptors at the parallel fiber-Purkinje cell synapse. J Neurophysiol 68: 1453-1462, 1992.

Hamm HE. The many faces of $\mathrm{G}$ protein signaling. J Biol Chem 273: $669-672,1998$

Herlitze S, Hockermann GH, Scheuer T, and Catterall WA. Modulation of $\mathrm{Ca}^{2+}$ channels by G-protein $\beta \gamma$ subunits. Nature 280: 258-262, 1996.

Hille B. Modulation of ion-channel function by G-protein-coupled receptors. Trends Neurosci 17: 531-536, 1994.

Hodgkin AL and Huxley AF. A quantitative description of membrane current and its application to conduction and excitation in nerve. J Physiol 117: $500-544,1952$.

Hounsgaard $\mathbf{J}$ and Midtgaard $\mathbf{J}$. Intrinsic determinants of firing pattern in Purkinje cells of the turtle cerebellum in vitro. J Physiol 402: 731-749, 1988.

Ikeda SR. Voltage-dependent modulation of N-type calcium channels by G-protein $\beta \gamma$ subunits. Nature 380: 255-258, 1996.

Jaeger D and Bower JM. Prolonged responses in rat cerebellar Purkinje cells following activation of the granule cell layer: an intracellular in vitro and in vivo investigation. Exp Brain Res 100: 200-214, 1994.

Katz B and Miledi R. The role of calcium in neuromuscular facilitation. J Physiol 195: 481-492, 1968.

Llinás R and Sugimori M. Electrophysiological properties of in vitro Purkinje cell dendrites in mammalian cerebellar slices. J Physiol 305: 197-213, 1980.

Llinás R, Sugimori M, and Silver RB. Microdomains of high calcium concentration in a presynaptic terminal. Science 256: 677-679, 1992.

Lovinger DM, Tyler E, Fidler S, and Merritt A. Properties of a presynaptic metabotropic glutamate receptor in rat neostriatal slices. J Neurophysiol 69: 1236-1244, 1993.

Mandelblat Y, Etzion Y, Grossman Y, and Golomb D. Period doubling of calcium spike firing in a model of a Purkinje cell dendrite. J Comput Neurosci 11: 43-62, 2001.

Markram H, Gupta A, Uziel A, Wang Y, and Tsodyks MV. Information processing with frequency-dependent synaptic connections. Neurobiol. Learn Mem 70: 101-112, 1998.

Matveev V, Sherman A, and Zucker RS. New and corrected simulations of synaptic function. Biophys $J$ 83: 1368-1373, 2002.

Meir A, Bell DC, Stephens GJ, Page KM, and Dolphin AC. Calcium channel $\beta$ subunit promotes voltage-dependent modulation of $\alpha 1 \mathrm{~B}$ by $\mathrm{G} \beta \gamma$. Biophys J 79: 731-746, 2000.

Mirotznik RR, Zheng X, and Stanley EF. G-protein types involved in calcium channel inhibition at a presynaptic nerve terminal. J Neurosci 20: 7614-7621, 2000 .

Ohno-Shosaku T and Yamamoto C. Effects of metabotropic glutamate receptor agonists on excitatory and inhibitory transmissions in cultured rat hippocampal neurons. Brain Res 705: 337-340, 1995.

Patil PG, de Leon M, Reed RR, Dubel S, Snutch TP, and Yue DT. Elementary events underlying voltage-dependent G-protein inhibition of N-type calcium channels. Biophys J 71: 2509-2521, 1996.

Pragnell M, DeWaard M, Mori Y, Tanabe T, Snutch TP, and Campbell KP. Calcium channel subunit binds to a conserved motif in the I-II cytoplasmic linker of the $\alpha_{1}$ subunit. Nature 368: 67-70, 1994.

Qian J, Colmers WF, and Saggau P. Inhibition of synaptic transmission by neuropeptide $\mathrm{Y}$ in rat hippocampal area CA1: modulation of presynaptic $\mathrm{Ca}^{2+}$ entry. J Neurosci 17: 8169-8177, 1997.

Roche JP and Treistman SN. $\mathrm{Ca}^{2+}$ channel $\beta_{3}$ subunit enhances voltagedependent relief of G-protein inhibition induced by muscarinic receptor activation and $\mathrm{G}_{\beta \gamma} . J$ Neurosci 18: 4883-4890, 1998.
Rosenmund C and Stevens CF. Definition of the readily releasable pool of vesicles at hippocampal synapses. Neuron 862: 1197-1207, 1996.

Ruiz-Velasco V and Ikeda SR. Multiple G-protein $\beta \gamma$ combinations produce voltage-dependent inhibition of $\mathrm{N}$-type calcium channels in rat superior cervical ganglion neurons. J Neurosci 20: 2183-2191, 2000.

Sahara Y and Westbrook GL. Modulation of calcium currents by a metabotropic glutamate receptor involves fast and slow kinetic components in cultured hippocampal neurons. J Neurosci 13: 3041-3050, 1993.

Shen K-Z and Johnson SW. Presynaptic GABA $A_{B}$ and adenosine $A_{1}$ receptors regulate synaptic transmission to rat substantia nigra reticulata neurones. J Physiol 505: 153-163, 1997.

Shen W-X and Horn JP. Presynaptic muscarinic inhibition in bullfrog sympathetic ganglia. J Physiol 491: 413-421, 1996.

Simon $\mathbf{S}$ and Llinás R. Compartmentalization of the submembrane calcium activity during calcium influx and its significance in transmitter release. Biophys J 48: 485-498, 1985.

Stanley EF. Decline in calcium cooperativity as the basis of facilitation at the squid giant synapse. J Neurosci 6: 782-789, 1986.

Swartz KJ and Bean BP. Inhibition of calcium channels in rat CA3 pyramidal neurons by a metabotropic glutamate receptor. J Neurosci 12: 4358-4371, 1992.

Takahashi T, Forsythe ID, Tsujimoto T, Barnes-Davies M, and Onodera K. Presynaptic calcium current modulation by a metabotropic glutamate receptor. Science 274: 594-597, 1996.

Takahashi T, Kajikawa Y, and Tsujimoto R. G-protein-coupled modulation of presynaptic calcium currents and transmitter release by $\mathrm{GABA}_{\mathrm{B}}$ receptors. J Neurosci 18: 3138-3146, 1998.

Tang Y-G, Schlumpberger T, Kim T-S, Lueker M, and Zucker RS. Effects of mobile buffers on facilitation: experimental and computational studies. Biophys J 78: 2735-2751, 2000.

Trombley PQ and Westbrook GL. L-AP4 inhibits calcium currents and synaptic transmission via a G-protein-coupled glutamate receptor. J Neurosci 12: 2043-2050, 1992.

Tsodyks MV and Markram H. The neural code between neocortical pyramidal neurons depends on neurotransmitter release probability. Proc Natl Acad Sci USA 94: 719-723, 1997.

Williams S, Serafin M, Mühlethaler M, and Bernheim L. Facilitation of $\mathrm{N}$-type calcium current is dependent on the frequency of action potentiallike depolarizations in dissociated cholinergic basal forebrain neurons of the guinea pig. J Neurosci 17: 1625-1632, 1997.

Witcher DR, De Waard M, Sakamoto J, Franzini-Armstrong C, Pragnell M, Kahl SD, and Campbell KP. Subunit identification and reconstitution of the N-type $\mathrm{Ca}^{2+}$ channel complex purified from brain. Science 261: 486-489, 1993.

Wu L-G and Saggau P. Adenosine inhibits evoked synaptic transmission primarily by reducing presynaptic calcium influx in area CA1 of hippocampus. Neuron 12: 1139-1148, 1994.

Wu L-G and Saggau P. Presynaptic inhibition of elicited neurotransmitter release. Trends Neurosci 20: 204-212, 1997.

Yamada WM and Zucker RS. Time course of transmitter release calculated from simulations of a calcium diffusion model. Biophys $J$ 61: 671-682, 1992.

Zamponi GW, Bourinet E, Nelson D, Nargeot J, and Snutch TP. Crosstalk between $\mathrm{G}$ proteins and protein kinase $\mathrm{C}$ mediated by the calcium channel $\alpha_{1}$ subunit. Nature 385: 442-446, 1997.

Zamponi GW and Snutch TP. Decay of prepulse facilitation of N type calcium channels during $\mathrm{G}$ protein inhibition is consistent with binding of a single $\mathrm{G}_{\beta \gamma}$ subunit. Proc Natl Acad Sci USA 95: 4035-4039, 1998.

Zhou JY, Siderovski DP, and Miller RJ. Selective regulation of N-type Ca channels by different combinations of G-protein $\beta / \gamma$ subunits and RGS proteins. J Neurosci 20: 7143-7148, 2000.

Zucker RS and Regehr WG. Short-term synaptic plasticity. Ann Rev Physiol 64: 355-405, 2002. 